20. Stedman, E \& Stedman, E, Phil trans roy soc London B235 (1951) 565.

21. Stevely, W S \& Stocken, L A, Biochem j 100 (1966) $20 \mathrm{C}$.

22. - Ibid 110 (1968) 187.

23. Tobey, R A \& Ley, K D, J cell biol 46 (1970) 151.

24. Yamamura, H, Takeda, M, Kumon, A \& Nishizuka, Y, Biochem biophys res commun 40 (1970) 675.

Received April 29, 1971

\section{Symbiosis of bacteria with eggs of Dentalium at the vegetal pole}

W. L. M. GEILENKIRCHEN, L. P. M. TIMMERMANS, C. A. M. VAN DONGEN, W. J. A. ARNOLDS, Zoological Laboratory, University of Utrecht, Janskerkhof 3, Utrecht, The Netherlands, and Stazione Zoologica, Naples, Italy

After deposition of egg cells of Dentalium dentale L., hair-like protrusions, which are Feulgen-positive, are clearly visible at the vegetal pole. On checking the American species Dentalium antillarum it appeared that similar protrusions are visible in this species [1].

These protrusions are present on the polar lobe during first and second cleavage. In later development they are visible only on descendants of the D blastomere. From the D blastomere they are passed on to the cell $4 \mathrm{~d}$ or possibly $4 \mathrm{D}$. Ultimately, the protrusions move into the gastrocoel and can be traced in the trochophore larva.

Phase contrast (fig. 2) and electron micrographs indicate that the protrusions do not consist of a band of cilia or villi. Villi are found on the whole surface of the egg cell. The micrographs (figs 2,3) show that the protrusions consist of elongated bodies which are in close contact with the cell surface at the vegetal pole and restricted to this area. They adhere firmly to the cell surface, for they are not washed off during fixing and embedding procedures. These bodies have not been observed to extend into the cytoplasm.

Examination of the phase contrast and low power electron micrographs provides no clue as to the nature of the protrusions. At higher magnification, however, electron micrographs (fig. 4) clearly show that these protrusions resemble bacteria. In fact, owing to the applied fixation method for egg cells, the bacteria cannot be considered appropriately fixed (P. F. Elbcrs, pers. comm.). In order to establish the origin of these bacteria, free oocytes have been examined at a stage when they are still surrounded by a closed layer of follicle cells. It appears that the bacteria are present in the space between follicle cells and oocyte, and probably also in the follicle cells (fig. 5).

It may be concluded that the vegetal pole of Dentalium eggs bears bacteria which are carried into the embryo via the $4 \mathrm{~d}$ or $4 \mathrm{D}$ blastomere. Ultimately, they become in all probability located in the ovary. In fact these authors have obtained evidence, however inconclusive, of their presence there. In the ovary the bacteria may then be passed on to the generation of germ cells.

The specific localization at the vegetal pole and the possible significance of this symbiosis for the egg cell cannot be explained at this moment.

This work has been supported by a travel grant from the Netherlands Ministry of Education and Sciences. The kind help of $\mathrm{Mr} \mathrm{H}$. van Kooten in preparing the photographs and the critical advice of Dr P. F. Elbers of the Biological Ultrastructure Research Unit, Utrecht, are gratefully acknowledged.

\section{References}

1. Timmermans, L P M, Geilenkirchen, W L M \& Verdonk N H, J embryol exptl morphol 23 (1970) 245 .

Received May 17, 1971 

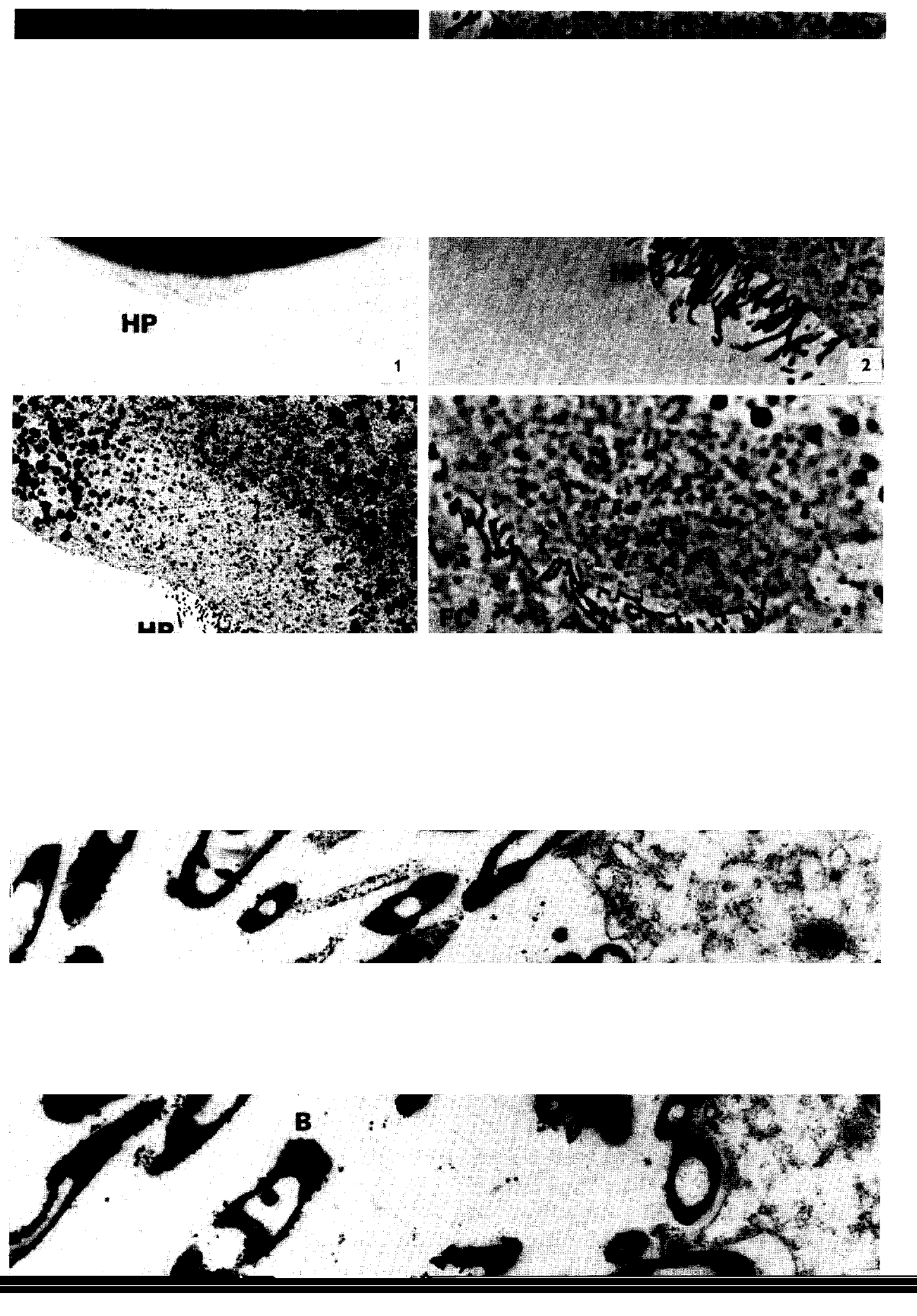